\title{
Development of a Video on Three-Dimensional Origami Creation Techniques to Improve the Practical Handicraft Skills of Teacher-Candidate College Students
}

\author{
Usep Kustiawan $^{1} \&$ Evania Yafie $^{1} \&$ Ence Surahman $^{2}$
}

\begin{abstract}
${ }^{1}$ Department of Primary School and Preschool Education, Faculty of Education, State University of Malang, Indonesia

${ }^{2}$ Department of Education Technology, Faculty of Education, State University of Malang, Indonesia Correspondence: Usep Kustiawan, State University of Malang, Indonesia.

Email: usep.kustiawan.fip@um.ac.id
\end{abstract}

doi: $10.23918 /$ ijsses.v7i2p79

\begin{abstract}
The aim of this research and development is to create a video on the creation techniques of threedimensional origami that is proper and effective as learning media for the handicrafts course for students of Teacher Education for Early Education at the State University of Malang. The utilized research method was Research and Development (R\&D). The stages of the research involved analysis of needs through instructional analysis, scenario development, video script development, footage recording, editing, and validation. The research results indicated that the developed video was declared valid and proper for usage as learning media based on evaluations from a media expert, material experts, and candidate users. Therefore, the developed media can be utilized to support the improvement of skills of candidate teachers for early education in the development of three-dimensional origami media products.
\end{abstract}

Keywords: Development, Handicrafts, Learning Video, Three-Dimensional Origami Creation Techniques

\section{Introduction}

The Teacher Education for Early Education Study Program of the Faculty of Education Science of the State University of Malang has the vision "to realize a Teacher Education for Early Education Study Program that possesses competitive, professional, and comparative advantages and becomes a reference for the three pillars (Tridharma) of higher education in the field of early education based on values of socio-culture, humanity, and religion”. Teacher Education for Early Education Study Program students, in addition to being prepared as candidates for teachers in early education institutions (Islamic preschool, playgroup, preschool) are also prepared by the study program to possess expertise in the field of early education "edutainment".

Teacher Education for Early Education Study Program students are expected to become entrepreneurs in the field of early education, whether independently or in cooperation with other people and/or institutions to produce goods and execute services in relation to preschool-age children. To develop the entrepreneurial spirit of Teacher Education for Early Education Study Program students, in addition to being provided with entrepreneurship-specific courses directed to the study of the development of entrepreneurship concepts and practices, also study entrepreneurship through other courses, among them the course of handicrafts. The practice materials for the course of handicrafts contain the material of origami (paperfolding) techniques that result in three-dimensional models that may be utilized for learning media and educational games for preschool-age children. One of the determining factors in coursework is the learning media. In selecting learning media, the lecturer should adjust according to the course type and student 
characteristics. If in a class the majority of students have a visual learning style, the lecturer should opt for the usage of visual media. If most of the students have an auditory learning style, the lecturer should utilize auditory media. Thus, if the students have an audiovisual learning style, the lecturer also ought to utilize audiovisual media. Considering that the course of handicrafts contains more practice materials, and that the characteristics of Teacher Education for Early Education Study Program students are heterogeneous, for these concerns, the research involves development of video learning media on the creation techniques of three-dimensional origami.

The need for visual media that can aid students in studying techniques in the creation of three-dimensional origami becomes an important one. This is based on the consideration of the limited time for demonstrating the practices of three-dimensional origami creation directly in the classroom. In addition, the great number of students presents its own challenge for their support and advising. Video media is expected to be able to replace the role of the lecturer in the instruction for the creation of origami and can be replayed as needed when the students require explanations.

Video media, according to Arsyad (2002) is a kind of media that depicts an object accompanied by audio or sounds simultaneously and appropriately. Learning media is anything that is utilized by a teacher to deliver learning materials to students to attract their interest and attention as well as to stimulate their learning process in order to achieve the objectives of learning (Kustiawan, 2017; Ramadhani \& Kustiawan, 2017). As well, Ibrahim (2006) has the view that video media is media that presents images and sounds (visuals and audio) in a simultaneous manner.

Video media is frequently utilized for learning needs at all levels of education. This is the case because the visualizations in video media possess an appeal for its users (Astuti, 2017). In addition, video media makes it easy for its users to comprehend the message being delivered (Fakhriyah, Ardianti, Savitri Wanabuliandari, \& Erlianti, 2018; Pramana \& Suarjana, 2019). Therefore, many researchers, teachers, and practitioners of education utilize video media as an alternative learning media.

Learning videos are a kind of media that is classified as digital visual media because they are developed with media creation applications. To develop good video media, developers must understand the standards of the development process of videos for learning needs (Riyana, 2007). Some of the components that must be included in the content of learning videos are the targeted material objectives, the materials, and follow-up in the form of assigned tasks that can be performed by users of the media after having viewed the materials presented in the video (Tarisci, 2017).

In this research, the developed video is for a creation tutorial of three-dimensional origami for the course of handicrafts. The objective of developing the video is to make it easier for the students to create forms of origami in three dimensions. The word "origami" comes from Japanese, a combination of the words ori meaning "to fold" and kami meaning "paper"; the combining of the two words results in a slight change of the form of the word kami into gami but does not change its meaning (Munqidzah \& Ustianingsih, 2018; Wardhani, Irawan, \& Sa'dijah, 2016; Yang, Yin, \& Chen, 2014). The resulting form is not "orikami" but "origami", meaning "to fold paper". The word "origami" has become recognized and used around the world to refer to the art of folding paper, and as such the art of folding paper certainly requires the material of paper. There are standard paper characteristics for easy and convenient folding, for example strong but thin paper (Ismayanti, 2005). 


\section{Research Methods}

The utilized method for this research is Research \& Development (R\&D). The procedure for the research and development of a learning video utilized the research and development procedure of Borg \& Gall (Gall, Borg, and Gall, 2003). Overall, the research and development covers the initial research, instructional design, product composition and development, and product validation. The Borg \& Gall method was selected because the method can be adjusted to the conditions of subjects and the field.

For this research, the stages of the Borg and Gall model was modified into seven stages: 1) research and collection of information, 2) planning, 3) product development, 4) validation and initial product testing, 5) product revision, 6) field testing, and 7) final product revision (Gall et al., 2003). Each stage was performed one by one in order to ensure that the research process occurred according to the plan.

The data collection technique in this research involved the usage of a few kinds of measurement instruments, as questionnaires for media validation and video material validation as well as a test of user competence before and after viewing the video. The objective is to measure the change in understanding before and after viewing the materials in the video. The aspects measured in the validation questionnaire by material and media experts are ease of operation, attractiveness of appearance, clarity of presented information, message completeness, and ease of understanding the presented message sequence (Hanum, Huda, \& Kurniawan, 2018; Riyana, 2007; Shuldman \& Tajik, 2010).

The utilized data analysis technique in this research was qualitative analysis and quantitative analysis based on percentages. Qualitative analysis was performed to analyze qualitative data collected from the experts. Quantitative analysis using percentages was performed to quantify the resulting data collected from the experts and the pre-test and post-test results of students in the practice of three-dimensional origami creation. The results of the data analysis were utilized to measure the validity and feasibility of the video media as well as the improvement in understanding of users toward the materials presented in the video.

\section{Result}

The resulting product from this research is a developed video media in the form of a single video that is packaged into a DVD (Digital Video Disc); the material presented in the video is creation techniques for three-dimensional origami, covering the understanding of origami, tools and items for creating threedimensional origami, steps to create eight kinds of three-dimensional origami, and examples of finished works of three-dimensional origami.

The usage of this product is considered easy because its usage only requires the disc to be played on a computer or laptop that is projected to a screen with an LCD projector, or in a DVD player that is connected to a large monitor or television. For its usage, this product is accompanied by a supplementary book of materials on the theories of three-dimensional origami to help students further understand the materials that are presented in the video.

Results of validation from the media expert led to a score of $92.25 \%$ for the video media of creation techniques for three-dimensional origami, and thus the developed video media of creation techniques for three-dimensional origami is judged to be quite fitting and appropriate for usage. The media expert commented that the media is very good and suggested that the cover of the video and book of supplementary materials, which initially only contained the title, names of developers, and identity of the 
institution that created the video media, be revised to include illustrations of finished works of threedimensional origami in order to attract interest.

Table 1: Product Revision Based on Suggestions from the Media Expert

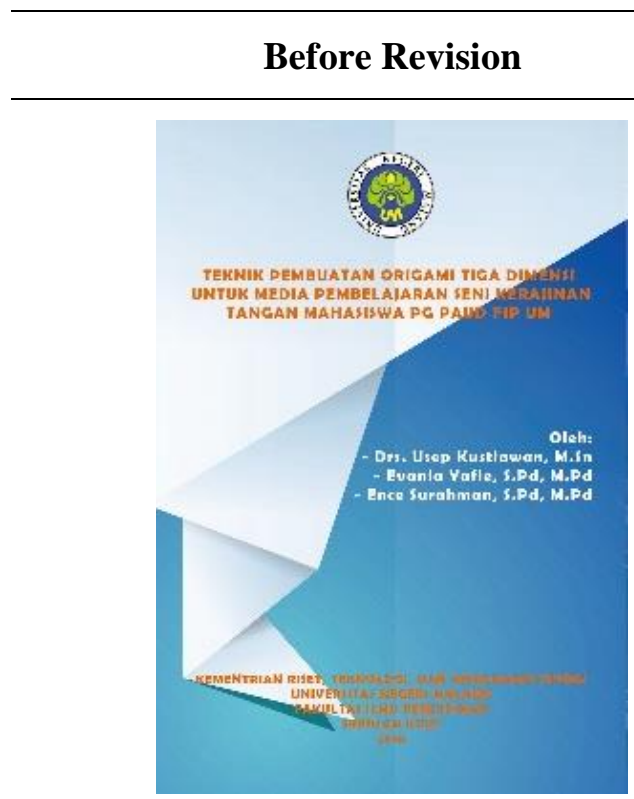

The video cover only contained the title, names of developers, and identity of the institution that created the video media of "Creation of ThreeDimensional Origami”.
After Revision

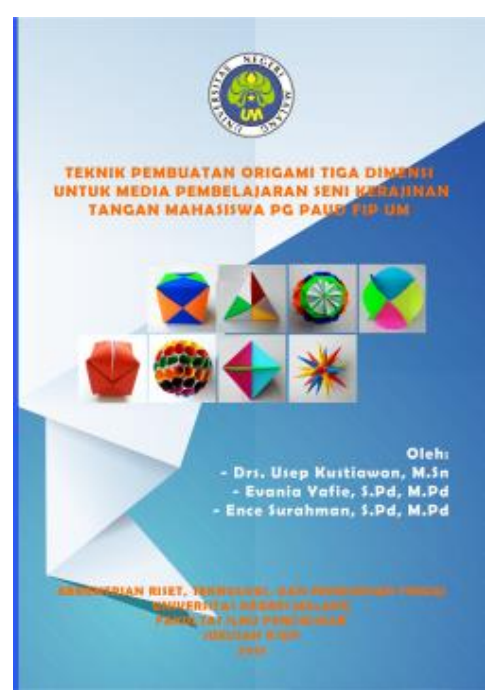

The cover of the "Creation of Three-Dimensional Origami" video media was supplemented with illustrative images of finished works of threedimensional origami.

Results of validation from material expert 1 led to a score of $88.75 \%$ for the video media of creation techniques for three-dimensional origami, and thus the developed video media of creation techniques for three-dimensional origami is judged to be quite fitting and appropriate for usage. Material expert 1 commented that the media is very good, easy, and appropriate for Teacher Education for Early Education Study Program students. Results of validation from material expert 2 led to a score of $85 \%$ for the video media of creation techniques for three-dimensional origami, and thus the developed video media of creation techniques for three-dimensional origami is judged to be quite fitting and appropriate for usage. However, material expert 2 commented that although the video media is appropriate for Teacher Education for Early Education Study Program, it was still suggested that at the end of the video, assigned tasks should be added to motivate students to create forms of three-dimensional origami. 
Table 2: Product Revision Based on Suggestions from Material Expert 2

\section{Before Revision}

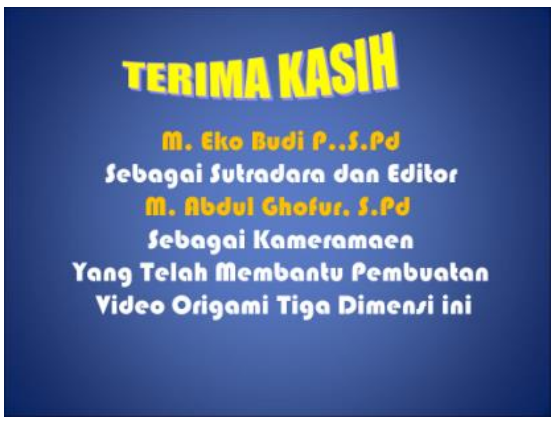

At the end of the video, only the rolling caption of gratitude to parties who assisted the making of the "Creation of ThreeDimensional Origami" video media is displayed.

\section{After Revision}

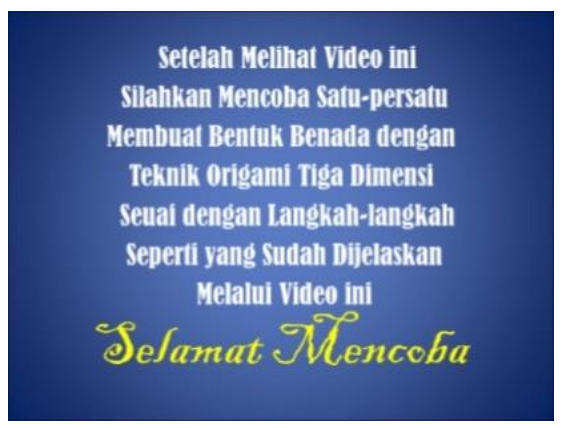

At the end of the video, assigned tasks were added to motivate students to create forms of three-dimensional origami, prior to displaying the rolling caption of gratitude to parties who assisted the making of the "Creation of Three-Dimensional Origami" video media.

Table 3: Pre-Test Scores of Three-Dimensional Origami Creation

\begin{tabular}{cccccc}
\hline No. & Name & Achieved Score & Maximum Score & Constant & Total Score \\
\hline 1. & AR & 8 & 16 & 100 & 50 \\
\hline 2. & BR & 10 & 16 & 100 & 62.5 \\
\hline 3. & IZ & 9 & 16 & 100 & 56.25 \\
\hline 4. & LC & 11 & 16 & 100 & 68.75 \\
\hline 5. & SK & 10 & 16 & 100 & 62.5 \\
\hline 6. & SM & 9 & 16 & 100 & 56.25 \\
\hline \multicolumn{7}{r}{} & Total & & $\mathbf{3 5 6 . 2 5}$ \\
\hline
\end{tabular}

Table 4: Post-Test Scores of Three-Dimensional Origami Creation

\begin{tabular}{cccccc}
\hline No. & Name & Achieved Score & Maximum Score & Constant & Total Score \\
\hline 1. & AR & 11 & 16 & 100 & 68.75 \\
\hline 2. & BR & 14 & 16 & 100 & 87.5 \\
\hline 3. & IZ & 13 & 16 & 100 & 81.25 \\
\hline 4. & LC & 15 & 16 & 100 & 93.75 \\
\hline 5. & SK & 14 & 16 & 100 & 87.5 \\
\hline 6. & SM & 13 & 16 & 100 & 81.25 \\
\hline \multicolumn{7}{r}{ Total } & & $\mathbf{5 0 0}$ \\
\hline
\end{tabular}


For the results of student practice in creating three-dimensional origami, it was found that the scores of all students who had taken the pre-test improved. On the post-test, subject 1 had a score of 68.75 , subject 2 had a score of 87.5 , subject 3 had a score of 81.25 , subject 4 had a score of 93.75 , subject 5 had a score of 87.5 , and subject 6 had a score of 81.25. Therefore, it can be concluded that the scores of subjects 1 to 6 who completed the field test improved. Based on these results, it can be interpreted that the video media for creation techniques of three-dimensional origami was judged to be fitting and appropriate for usage. The average of obtained scores for the post-test based on the effectiveness criteria for utilization of learning media is within the score range of 81.00-100.00, meaning that it is quite valid and can be utilized without further revisions.

\section{Discussion}

A good quality learning process at the university level requires support from appropriate learning resources. Learning resources constitute anything that can become materials and tools to support learners in gaining learning experience in order to achieve the objectives of learning (Koper, 2003). One of the sources for learning that may be utilized is learning media. Learning media is a facility to deliver messages of learning from a source of learning to learners (Sihkabuden, 2005). There are several forms of learning media that are utilized in learning at the university level. One of these kinds of media is video media. Video media is media that displays visuals (moving images) and audio (sound) simultaneously, and therefore students in grasping the materials will utilize their senses of vision and hearing at the same time (Potdevin et al., 2018; Woottipong, 2014).

A learning media can be said to be effective and appropriate for usage if it is able to provide stimulus to students, thereby improving the results of learning by the students. As with the results of the research that has been performed, the developed video media was able to stimulate learners. This is because the presenter explained the materials for three-dimensional origami creation techniques using a variety of communication methods, as through simultaneous spoken language and gestures as well as text on screen, which aids the students in understanding the material content in the video as measured among the users of the media.

The video media for three-dimensional origami creation techniques possesses many benefits for both educators and learners, one of them being to motivate student interest; this is apparent in the direct practice of the creation of different kinds of three-dimensional origami by the presenter that make students interested to follow along, the short length of the video that does not cause disinterest, and the accompaniment of illustrations of finished works of the different kinds of three-dimensional origami. This is in line with the results of a study (Ehrenstein, 2019) that showed that video media is able to improve motivation and concentration in paying attention to the learning materials.

Another advantage of video media based on the results of this research is the capability of presenting information about the techniques of three-dimensional origami; this video explains the understanding of origami, two-dimensional origami, and three-dimensional origami as well as the tools and items to create three-dimensional origami, the steps to create eight kinds of three-dimensional origami, and examples of finished works of eight kinds of three-dimensional origami. This is in line with the results of the research conducted by Abe \& Nosu (2017) who found that video media is able to present information clearly and can be repeated many times over. Another advantage of video media is the variation in communication; 
technically, the presenter utilized total communication with the usage of spoken language, gestures, and supplementary narration. This is in line with the research results from a number of researchers (Mulyono, Abidin, \& Husna, 2019; Saprudin, Haerullah, Abdullah, Saraha, \& Hamid, 2018)

In general, the developed product of video media on three-dimensional origami techniques possesses these advantages: (1) it is easy to use; (2) its usage only requires a short time to explain the practice of techniques to create eight kinds of three-dimensional origami (approximately 40 minutes) for which the actual practice requires spending two to three hours; (3) it is accompanied by a supplementary book of materials, which makes it easier for students in their usage; and (4) its appearance is appropriate to the needs and conditions of usage by students in campus and outside of campus. This is in line with the results of prior research as conducted by a few researchers (Hanum et al., 2018; Nawawi, Degeng, \& Cholid, 2019; Rozie, 2014) who concluded that video media is suitable to be developed to assist in delivery of procedural materials. In this way, learners can understand effectively and efficiently.

In broader practice, video media is developed to ease the delivery of materials that demand learners to practice actions that are demonstrated in the video. One example is a research (Anam, Sugiarto, \& Wahyudi, 2017) that involved the development of a video for the needs of technical materials on basic swimming. The results showed that the developed media positively contributed to the learners. Another example of usage is for the needs of materials on dance moves as conducted by several researchers (Ida Ayu, Ni Luh, \& Ni Wayan, 2018; Kompyang Gede, Ni Luh, \& I Ketut, 2018; Ni Kadek, I Gede, \& Ni Luh, 2018; Putu, Pradana, Ni Luh, \& Rinto, 2018; Sonalitha, Yuniarti, Prihatiningsih, \& Prasetya, 2017) who concluded that the dancing skills of students may be improved through presentation of example dance movements in video media.

The latest developments of video media for learning involve the creation of mobile learning applications, such as that which was performed in some studies (Iqbal, 2019; Listiyanti, Syahbana, \& Henim, 2016), which resulted in findings about the effectiveness of learning results with the use of video media in an Android application. At this time, there is much development of media using Android to support learning, and this is due to the efficiency of the resulting application (Surahman \& Alfindasari, 2017; Surahman \& Surjono, 2017). This cannot be removed from improvement of human resources in the effort to integrate technology in order to improve the quality of learning (Alfindasari \& Surahman, 2014; Praherdhiono et al., 2019).

The most recent developments of video media for learning are implemented in the form of augmented reality such as that which was conducted by several groups of researchers (Guenter \& Gal, 2019; Wang, Suenaga, Yang, Kobayashi, \& Sakuma, 2017; Yip, Wong, Yick, Chan, \& Wong, 2019), and this has an advantage in terms of interesting media presentation and flexibility in usage. The results of media development can be used not only for classical face-to-face learning but also quite possibly in the context of online learning (Ayers et al., 2018). The results of findings as explained previously can become alternatives in the development of video media for learning at present and in the future.

\section{Conclusion}

The final results of this product development are the validation results from the media expert, material expert 1 , and material expert 2 , as well as the test results. The "Creation Techniques of Three-Dimensional 
Origami" video media is considered appropriate and effective to be used in courses. This is based on the results of validation evaluation: the media expert gave a score of $92.25 \%$ (quite appropriate), material expert 1 gave a score of $88.75 \%$ (quite appropriate), material expert 2 gave a score of $85 \%$ (quite appropriate), and the average pre-test score of students (59.375) improved after the post-test to an average student score of 83.33. From the overall results of development, it can be concluded that the "Creation Techniques of Three-Dimensional Origami" video media is quite appropriate to be used in courses to assist lecturers in explaining the material of techniques of creating different kinds of three-dimensional origami for the handicrafts course of the Teacher Education for Early Education Study Program of the Faculty of Education Science of the State University of Malang.

\section{Suggestions}

Based on the results of the conducted development, it is recommended that the video on three-dimensional origami creation techniques be distributed to and utilized by college students as well as school teachers. The follow-up to the results of this research may be in the form of conducting activities to serve teachers in the effort to improve skills of creating three-dimensional origami.

\section{Acknowledgements}

We are grateful to the participants of this study, and the journal editors and reviewers for their insightful comments on earlier versions of this manuscript.

\section{References}

Abe, M., \& Nosu, K. (2017). Video and Utterance Analysis of Male University Students Making Origami. Proceedings of the International Conference on Advances in Image Processing, 165168.

Alfindasari, D., \& Surahman, E. (2014). Sumber Daya Manusia dan Pendidikan di Era Global: Sebuah Tinjauan Terhadap Penelitian Teknologi Pendidikan di LPTK. Proceeding Seminar Nasional Teknologi Pembelajaran. Yogyakarta: UNY.

Anam, M. S., Sugiarto, T., \& Wahyudi, U. (2017). Pengembangan Variasi Latihan Teknik Dasar Renang Gaya Bebas Dan Gaya Dada Melalui Video Compact Disk Pada Kegiatan Ekstrakurikuler Renang Di SMP Negeri 8 Malang. Gelanggang Pendidikan Jasmani Indonesia, 1(1), 74-86.

Arsyad, A. (2002). Media pembelajaran, edisi 1. Jakarta: PT. Raja Grafindo Persada, 36.

Astuti, D. B. (2017). Pengaruh Daya Tarik Iklan Quipper Video Terhadap Motivasi Belajar (Survei Pengikut Fanspage Facebook Quipper Video). Universitas Pembangunan Nasional Veteran Jakarta.

Ayers, R. K., Bean, C., Brown, K. C., Chiarella, G. G., Wishart, A. E., \& Wood, J. J. (2018, September 11). Synchronizing an augmented reality video stream with a displayed video stream. Google Patents.

Ehrenstein, D. (2019). Focus: Video-Tunable Origami. Physics, 12, 44.

Fakhriyah, F., Ardianti, S. D., Savitri Wanabuliandari, L., \& Erlianti, S. (2018). Analisis Penguasaan Konsep Pembelajaran Sistem Reproduksi dengan Video Contextual Teaching and Learning di SMA. SEMNAS BIO VI, 21.

Gall, M. D., Borg, W. R., \& Gall, J. P. (2003). Educational research: An introduction. Longman Publishing.

Guenter, B. K., \& Gal, R. (2019, September 19). Video noise reduction for video augmented reality system. Google Patents. 
Hanum, N. L., Huda, A., \& Kurniawan, A. (2018). Development of instructional video media in increasing sex education knowledge for students with hearing impairment. Jurnal Penelitian Dan Pengembangan Pendidikan Luar Biasa, 5(1), 62-66.

Ibrahim. (2006). Media Pembelajaran. Malang: Universitas Negeri Malang.

Ida Ayu, S. W., Ni Luh, S., \& Ni Wayan, I. (2018). Pengembangan Video Pembelajaran Tari Cempaka Putih Pada Ekstrakurikuler Di SMA Negeri 2 Mendoyo Kabupaten Jembrana.

Iqbal, D. (2019). Implementasi Algoritma Levenstein Untuk Kompresi File Video Pada Aplikasi Chatting Berbasis Android. KOMIK (Konferensi Nasional Teknologi Informasi Dan Komputer), $3(1)$.

Ismayanti, F. (2005). Origami dan Anak.

Kompyang Gede, A. D. P., Ni Luh, S., \& I Ketut, K. (2018). Pengembangan Video Pembelajaran Teknik Gerak Dasar Tari Bali Putra Di SMA Negeri 6 Denpasar.

Koper, R. (2003). Combining reusable learning resources and services with pedagogical purposeful units of learning. In Reusing online resources (pp. 64-77). Routledge.

Kustiawan, U. (2017). The Development of Diorama Learning Media Transportation Themes to Develop Language Skill Children's Group B. Research on Education and Media, 9(2), 26-31.

Listiyanti, D., Syahbana, Y. A., \& Henim, S. R. (2016). Perancangan dan Implementasi Aplikasi Android Penentu Salient Area pada Video dengan Algoritma K-Medoids. ANNUAL RESEARCH SEMINAR, 2016.

Mulyono, A. B., Abidin, Z., \& Husna, A. (2019). Pengembangan Media Video Pengoperasian Kamera DSLR Sebagai Suplemen Mata Pelajaran Di Jurusan Multimedia. Jurnal Kajian Teknologi .... Retrieved from http://journal2.um.ac.id/index.php/jktp/article/view/290

Munqidzah, Z., \& Ustianingsih, L. (2018). Pelatihan Origami Bagi Guru-Guru PAUD Untuk Meningkatkan Profesionalisme Guru. JPM (Jurnal Pemberdayaan Masyarakat), 3(1), 246-251.

Nawawi, N., Degeng, N., \& Cholid, A. (2019). Development of Video Media to Increase Dribbling Learning Result in A Sport Games. Edcomtech Jurnal Kajian Teknologi Pendidikan, Vol. 4, pp. 83-88. https://doi.org/10.17977/um039v4i22019p083

Ni Kadek, M. P., I Gede, M., \& Ni Luh, S. (2018). Pengembangan Video Pembelajaran Tari Cendrawasih di SMA Negeri 6 Denpasar.

Potdevin, F., Vors, O., Huchez, A., Lamour, M., Davids, K., \& Schnitzler, C. (2018). How can video feedback be used in physical education to support novice learning in gymnastics? Effects on motor learning, self-assessment and motivation. Physical Education and Sport Pedagogy, 23(6), $559-574$.

Praherdhiono, H., Setyosari, P., Degeng, I. N. S., Slamet, T. I., Surahman, E., Adi, E. P., ... Abidin, Z. (2019). Teori dan Implementasi Teknologi Pendidikan: Era Belajar Abad 21 dan Revolusi Industri 4.0. Seribu Bintang.

Pramana, I. P. Y., \& Suarjana, I. M. (2019). Pengaruh Model Pembelajaran Time Token Berbantuan Media Video Terhadap Hasil Belajar IPA Kelas V SD. Journal of Education Technology, 2(4), 137-144.

Putu, I., Pradana, E. V., Ni Luh, S., \& Rinto, W. (2018). Pengembangan Video Pembelajaran Tari Wirayuda Di Sekolah Dasar Negeri 3 Ubud, Gianyar.

Ramadhani, P. K., \& Kustiawan, U. (2017). The Effect of the Big Book Media Usage to Simple Sentences' Reading Ability for Third Grader with Intellectual Disability on Elementary School for Special Needs. Journal of ICSAR, 1(1), 42-45.

Riyana, C. (2007). Pedoman pengembangan media video. Jakarta: P3ai Upi.

Rozie, F. (2014). Development of Recycling Water Media Video Learning to Improve Processes and Learning Outcomes IPA Elementary Students. Jurnal Pendidikan Sains, 1(4), 413-424.

Saprudin, S., Haerullah, A. H., Abdullah, I. H., Saraha, A. R., \& Hamid, F. (2018). Pengembangan Media Video Tutorial Model Discovery Learning Materi Tekanan Hidrostatis. In Prosiding Seminar Kontribusi Fisika 2017, Pp. 300-304. 
Shuldman, M., \& Tajik, M. (2010). The role of media/video production in non-media disciplines: the case of health promotion. Learning, Media and Technology, 35(3), 357-362. https://doi.org/10.1080/17439884.2010.508991

Sihkabuden, S. P. (2005). Media Pembelajaran. Malang: Elang Press.

Sonalitha, E., Yuniarti, S., Prihatiningsih, B., \& Prasetya, A. Y. (2017). Peningkatan Pelestarian Seni Tari Wayang Orang Melalui Video Pembelajaran. Jurnal Pengabdian Masyarakat Universitas Merdeka Malang, 2(1).

Surahman, E., \& Alfindasari, D. (2017). Developing Adaptive Mobile Learning with the Principle of Coherence Mayer on Biology Subjects of High School to Support the Open and Distance Education. 3rd International Conference on Education and Training (ICET 2017). Atlantis Press.

Surahman, E., \& Surjono, H. D. (2017). Pengembangan adaptive mobile learning pada mata pelajaran biologi SMA sebagai upaya mendukung proses blended learning. Jurnal Inovasi Teknologi Pendidikan, 4(1), 26-37. https://doi.org/10.21831/jitp.v4i1.9723

Tarisci, M. (2017). Pembuatan Media Video Pembelajaran Dan Implementasi Terhadap Hasil Belajar Pada Materi Kultur Jaringan Di SMA Muhammadiyah 09 Kualuh-Hulu Tp 2016/2017.

Wang, J., Suenaga, H., Yang, L., Kobayashi, E., \& Sakuma, I. (2017). Video see-through augmented reality for oral and maxillofacial surgery. The International Journal of Medical Robotics and Computer Assisted Surgery, 13(2), e1754.

Wardhani, D., Irawan, E. B., \& Sa'dijah, C. (2016). Origami terhadap Kecerdasan Spasial Matematika Siswa. Jurnal Pendidikan: Teori, Penelitian, Dan Pengembangan, 1(5), 905-909.

Woottipong, K. (2014). Effect of Using Video Materials in the Teaching of Listening Skills for University Students. International Journal of Linguistics, 6(4). https://doi.org/10.5296/ijl.v6i4.5870

Yang, H. H., Yin, S. K., \& Chen, P. Y. (2014). Design and Implementation for the Web of Origami Simulator. Applied Mechanics and Materials, 536, 593-598. Trans Tech Publ.

Yip, J., Wong, S.-H., Yick, K.-L., Chan, K., \& Wong, K.-H. (2019). Improving quality of teaching and learning in classes by using augmented reality video. Computers \& Education, 128, 88-101. 